\title{
In situ investigation of stone heritage sites for conservation purposes: a case study of the Székesfehérvár Ruin Garden in Hungary
}

\author{
Magdalini Theodoridou ${ }^{1 *}$ (D) and Ákos Török ${ }^{2}$
}

\begin{abstract}
This paper demonstrates the application of in situ diagnostic tools to document stone heritage sites prior to conservation interventions using a Medieval ruin of Central Europe (Székesfehérvár, Hungary). The applied methods included lithological mapping and characterisation and mapping of decay forms as well as in situ measurements of physical parameters such as Schmidt hammer rebound, moisture content and micro-drilling resistance. The combination of these methods allowed the condition assessment of different lithotypes and demonstrated the role of micro-fabric, mineralogical composition and climatic conditions in stone durability. Differences were found in the properties and in the weathering forms of fine-grained and medium-grained porous oolitic limestone and travertine. The black crust observed in porous limestone is less prone to detachment on medium-grained oolitic limestone ashlars, while scaling was observed on fine-grained oolitic limestone blocks. The micro-drilling resistance of exposed porous limestone showed higher drilling resistance at the crust zone (upper 1-2 mm) than below, marking the upper cemented zone, while the drilling resistance of porous limestone under shelter showed an opposite trend. The shelly limestone, the sandy calcarenite and red compact limestone also showed an increase in drilling resistance at the topmost app. $2 \mathrm{~mm}$ zone. The applied in situ, non-invasive and micro-destructive techniques helped in the identification of endangered zones at Székesfehérvár, thus, they can provide key information on condition assessment of stones at heritage sites, where sampling is limited and preventive conservation is important.
\end{abstract}

Keywords: Conservation science, Built heritage, Stone damage assessment, In situ evaluation, Non-destructive techniques, Mapping, Micro-drilling

\section{Introduction}

Tangible cultural heritage such as ruins or stone buildings needs special attention in terms of preservation and documentation (Jokilehto 1999). It has been noted previously that prior to any intervention and conservation, a detailed survey is needed to record architectural elements and materials used at the site (Török and Přikryl 2010; Přikryl 2013, 2017). Additional studies are needed to understand the behaviour of materials and their compatibility with any replacement stone, render or other compounds that are planned to be used (Beck and Al-Mukhtar 2008; Modestou et al. 2016; De Kock et al.

\footnotetext{
* Correspondence: THEODORIDOUM2@CARDIFF.AC.UK

'Cardiff School of Engineering, Cardiff University, Queen's Buildings, The

Parade, Cardiff, Wales CF24 3AA, UK

Full list of author information is available at the end of the article
}

2017). On the other hand, materials that form part of the structure suffer from deterioration over time (Schaffer 1932). The natural processes can be enhanced by various intrinsic and extrinsic factors such as (i) mineralogical and textural characteristic of rocks and materials (Přikryl 2007; Fort et al. 2010; Török and Přikryl 2010; Pappalardo et al. 2016; Pozo-Antonio et al. 2017), (ii) exposure conditions (Amoroso and Fassina 1983, Török et al. 2007a, 2007b, Graue et al. 2013), (iii) microclimate (Camuffo 1998), changes in climate (Brimblecombe and Grossi 2009; Gibeaux et al. 2018) or in natural processes and unexpected disasters (e.g. flood Kusar 2008, Siedel 2010); (iv) anthropogenic pollutants (Maravelaki-Kalaitzaki and Biscontin 1999; Bonazza et al. 2005; McAlister et al. 2008; Török et al. 2011; Calparsoro et al. 2017; La 
Russa et al. 2017) and (v) human activities, e.g. vandalism, or war (Mahgoub 2008).

The present study focuses on the diagnostics of a medieval ruin garden located in Hungary. It focuses on the geological composition of materials, exposure and air pollutants, as well as previous construction activities. The main line is related to the fact that, before any intervention, a detailed survey of stone conditions is necessary (Drury 2006). The monument, which is comprised of different construction materials (e.g. various stones and mortars), needs a complex diagnostic approach. In this case, the role of earth scientists is crucial (Přikryl 2007). The diagnostic survey can have a very broad context referring to geotechnical studies concerning the ground support and groundwater table; geomaterials characterisation from lithological description to detection of weathering forms and finally to measuring on site physico-mechanical properties and mineralogical and chemical composition. This paper focuses on the latter two aspects, namely the description of lithotypes and weathering forms and also the measurements of the physico-mechanical properties of stones found at the Székesfehérvár Ruin Garden. The
Garden is an exceptional assemblage of monuments and a protected cultural heritage site of Hungary documenting long history from the Roman period to the present. The methodology presented here can also be applied in other parts of the world for documenting and describing cultural heritage sites prior to any conservation measures and also for planning restoration.

\section{History and site description}

The Ruin Garden is located in the historical centre of the city of Székesfehérvár $(65 \mathrm{~km}$ southwest of Budapest in Hungary) (Fig. 1). In the Middle Ages (eleventh and twelfth centuries), the city was a Royal residence and, until the Turkish occupation in 1543, one of the most important cities of Hungary. This is also supported by the etymology of the city's name which translates into English as "white castle with the seat" with the word "seat" referring to the throne of the king. The Ruin Garden of Székesfehérvár (Fig. 2) served in the Middle Ages as the coronation church for the kings of the Hungarian Christian Kingdom and the burial place for fifteen kings, several members of the royal families and, later on, of

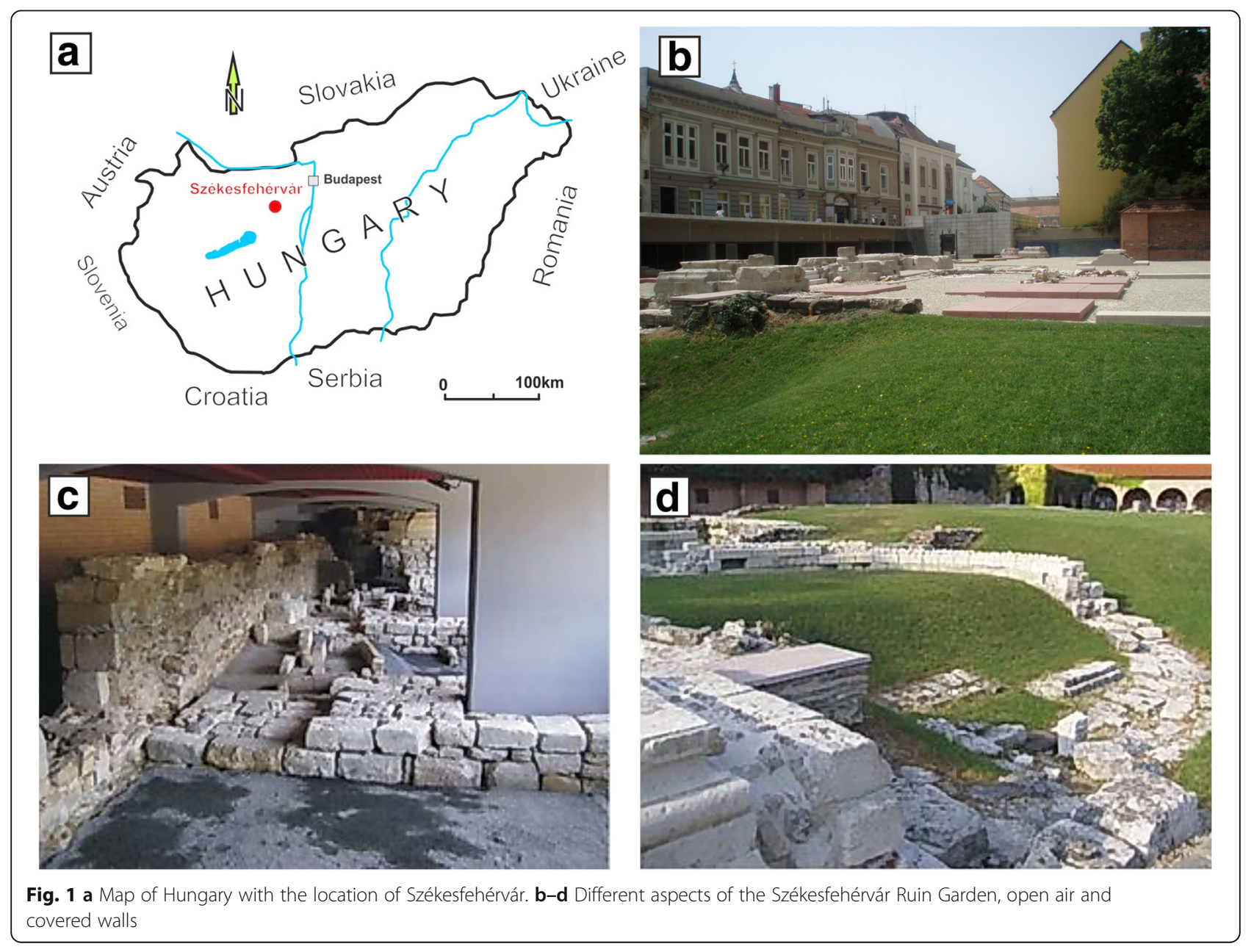




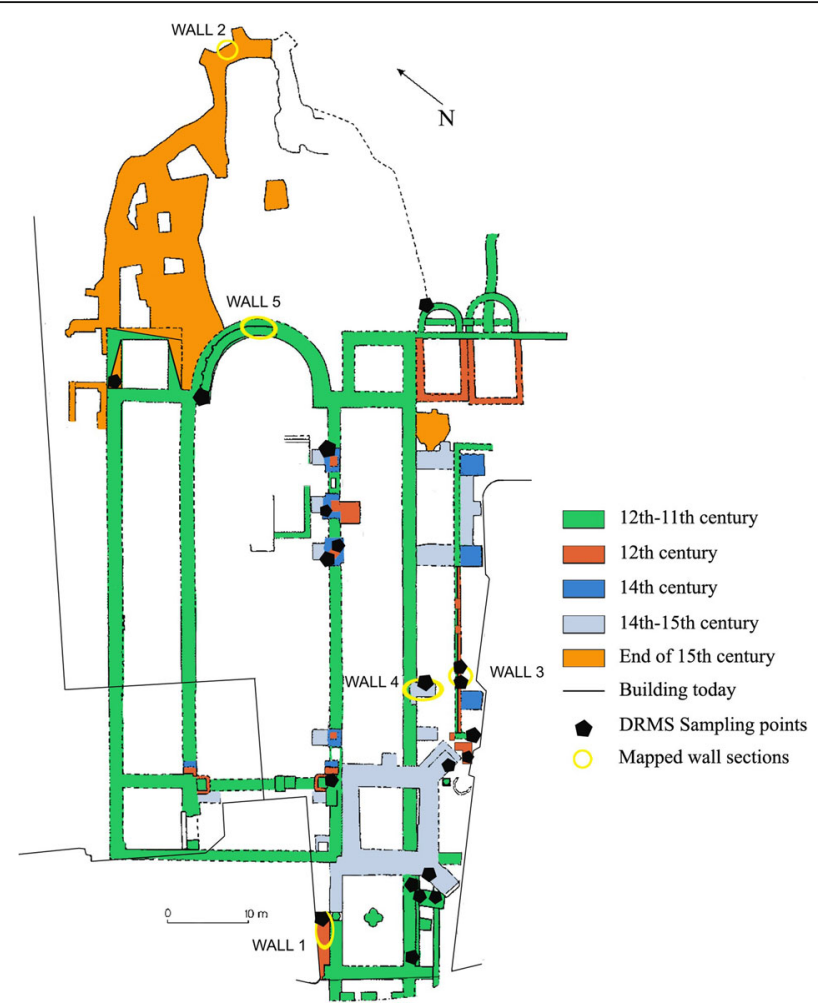

Fig. 2 Map of excavated ruins of the Székesfehérvár Ruin Garden depicting their different periods of construction and the main sampling points (modified after Bartos et al. 2004)

the high nobility. It was also the home of the royal treasury and relics. It is comprised of a provostal church dedicated to Virgin Mary, called today "Royal Basilica", royal tombs and related ecclesial and lay buildings. Since it has been nominated for "National Memorial Place", its present and future protection is required.

Between the eleventh and the fifteenth centuries, it was reconstructed several times. The first phase of construction took place during the eleventh to twelfth centuries, under the Arpad Dynasty. During the Arpadian Age, in the twelfth century, the first rebuilding took place. Damage from several fires necessitated the first gothic reconstruction work that started in 1318, during the Anjou Dynasty. Another fire in 1327 led to the second Gothic reconstruction (fourteenth to fifteenth centuries). The last expansion of the temple was implemented by King Matthias in the second half on the fifteenth century, in a Late-Gothic style (Biczó 2005).

Its several reconstructions and expansions throughout Hungarian history introduce another aspect of the importance of the historical site. A quick overview of the current state of the monument reveals the presence of several lithotypes that can be found among the remaining buildings and decorative stones. The research related to the materials in order to understand their composition, structure, origin and behaviour is therefore crucial not only for the conservation of that specific monument but also for a series of other historic structures in Hungary.

In the nineteenth century, the excavation by Imre Henszlmann revealed the size of the main parts of the church which was followed by several additional excavations (Theodoridou 2009). The total site of the excavated ruins is approximately $4700 \mathrm{~m}^{2}$. The palace of the bishop borders the excavation area on the northwest part of the Ruin Garden.

For the 900th anniversary of St. Stephen's death, after the excavation between 1936 and 1938, the Ruin Garden was open to the public and the ruins were shown to the visitors in their original condition before any intervention (Altmann et al. 1999). In the eastern part of the remains of the Monostorbástya, a museum of stone carvings and the mausoleum were erected. The stone tomb, which has been called St. Stephen's sarcophagus after the published study by Varjú in 1930, is placed in the aforementioned mausoleum. The place is open to the public and a high number of tourists are visiting the site.

\section{Methods/Experimental Mapping}

A series of maps were created based on investigations. Five representative wall sections were selected based on 
the distribution of the different lithotypes and the different construction periods to which the ruins belong (Fig. 2). Their location in the site, i.e. sheltered (walls 1 , 3 and 4) or unsheltered areas (walls 2 and 5), was also taken into account. The investigated side of wall 1 faces southeast, wall 2 north, wall 3 northwest, and wall 4 and 5 northeast. The total mapped area covered about $30 \mathrm{~m}^{2}$ of the existing wall surfaces (Theodoridou 2009). Three different kinds of maps were designed for each wall section: (i) the first series of maps depicts the different construction periods of the selected section of the walls, (ii) the second shows the distribution of the different lithotypes over the wall sections, and (iii) the visible weathering forms on the building materials. For the last category of mapping, the first classification was developed by the working group "Natural stones and weathering" (Fitzner et al. 1995) with several publications that followed, e.g. Fitzner and Heinrichs 2002, Fitzner et al. 1997, 2002, Viles et al. 1997 and the lately published glossary by ICOMOS-ISCS (2008).

\section{Non-destructive techniques Schmidt hammer}

The Schmidt hammer is a non-destructive test method that has been applied in situ for estimating strength. The working principle is a spring-loaded mass impacts the material and the rebound value is displayed at the Schmidt hammer. The rebound measurements are on an arbitrary scale ranging from 10 to 100 . Schmidt hammer is also used for detecting of weathering of stone monuments (Török 2003; Viles et al. 2011). For this study, a Digi 2 Schmidt hammer was applied. Measurements were made on the blocks of the five selected wall sections of the monument (Fig. 2). Ten values were acquired for each tested block and the extreme and mean values, in addition, to the standard deviation, were recorded.

The Schmidt hammer was originally developed for measuring the strength of hardened concrete (Schmidt 1951). Nevertheless, several studies have correlated its results to predict several stone properties (Török 2008). The correlation of the rebound values with the rock compressive strength is the most commonly studied, e.g. Miller 1965, Barton and Choubey 1977, Sachpazis 1990, Kahraman 2001. The use of the rebound values in the calculation of other mechanical properties has been also studied (Katz et al. 2000). Their state of weathering has also been estimated by evaluating the hammer rebound values (e.g. limestones: Bell 1993, Christaras 1996, Török 2003, Viles et al. 2011).

\section{Gann Hydromette}

An estimation of the structural moisture of the tested blocks can be very informative for the impact of climatic conditions. As a consequence, a correlation of the results with the materials weathering state may be possible. Furthermore, the obtained values, even in the case of numerical and not absolute ones, can be used in comparison with other measuring points and a profile of relative moisture content can be drawn (Török 2009). For this study, a Gann Hydromette Uni was used for an in situ and non-destructive estimation of the structural moisture. The moisture content values that can be obtained by the Gann Hydromette are given in 'digits' and they may range from 0 to 199 digits. When the measured relative values are more than a hundred units, the material is considered wet. Ten measurements were carried out on each tested block and the average value was calculated. The blocks that were measured belonged to the five selected wall sections of the monument (Fig. 2).

\section{Micro-destructive techniques Drilling Resistance Measurement System}

The DRMS cordless (Drilling Resistance Measurement System) by SINT Technology is a portable micro-destructive cutting technique that was developed for laboratory and in situ studies in heritage conservation (e.g. Exadaktylos et al. 2000; Singer et al. 2000; Tiano 2001; Delgado Rodrigues et al. 2002; Cnudde et al. 2008; Theodoridou and Ioannou 2015; Modestou et al. 2015). It has been proven that the results of this testing method correlate well with various laboratory measured physical and mechanical properties of weak to very strong limestones (Theodoridou et al. 2015). During the measurements, the necessary force for penetrating a certain depth in time was measured continually, while the penetration rate and rotational speed were kept constant. The outputs of the measurements were given in $x-y$ plots of the drilling force along the depth, and the data was registered in numeric values. The operating conditions were $600 \mathrm{rpm}$ for the rotational speed, 10 $\mathrm{mm} / \mathrm{min}$ for the penetration rate and $10 \mathrm{~mm}$ the total depth of penetration. The diameter of the diamond drill bits was $5 \mathrm{~mm}$. A total of 20 blocks of building stone (Fig. 2) was subjected to the measurement system. Different lithotypes, such as various kinds of limestone, marble and rhyolite were tested aiming at relating the results with their state of weathering, avoiding further invasive sampling.

\section{Results \\ Mapping}

The several construction periods of five selected wall sections were mapped, along with the distribution of the different lithotypes, highlighting the complexity of the monument (Theodoridou 2009). The properties of the identified lithotypes are summarised in Table 1, where 
Table 1 Identified lithotypes and their major characteristics

\begin{tabular}{llll}
\hline Lithology & Code & Description (mean open porosity \%) & Microscopic characteristics \\
\hline Ooidal peloidal limestone & OL & Creamy, coarse-grained highly porous (28\%) & Ooidal-peloidal packstone \\
Shelly limestone & SL & Creamy yellowish, fine-grained porous (23\%) & Shelly packstone \\
Polimict sandy calcarenite & SC & Brownish creamy, coarse-grained, porous (13\%) & Quartz-rich wackestone \\
Red biomicritic limestone & RL & Red nodular limestone with very low porosity (<1\%) & Wackestone \\
$\begin{array}{l}\text { Foraminifera-bearing } \\
\text { limestone }\end{array}$ & FL & Light yellowish creamy, very porous (19\%) & Peloid-microoncoid packstone \\
Travertine & T & Yellowish creamy, moderately porous (11\%) & Boundstone \\
Quartz-porphyry (rhyolite) & Rh & $\begin{array}{l}\text { Light brownish-purple brown with small phenocrysts of quartz and K- } \\
\text { feldspar (4\%) }\end{array}$ & Micro-crystalline porphyritic \\
Granite & Gr & Light red, fine-grained phaneritic (1\%) & Hypidiomorphic crystalline \\
Marble & M & Light greyish white coarse crystalline $(<1 \%)$ & Inequigranular with serrated crystal \\
& & & boundaries
\end{tabular}

the abbreviations (codes) of each lithology used in the text can be found.

Figures 3 and 4 show the maps of construction phases and lithotypes respectively of a representative wall section (wall section 1).

Based on the results of lithological mapping of the selected wall sections, several types of limestones such as ooidal peloidal (i.e. oolitic), travertine and bioclastic ones were the most widely used lithotypes in the different construction phases of the monument. Besides Figs. 3 and 4 that represent different types of limestone on the different construction phases of wall 1, oolitic, red compact, sandy, marly sandy, bioclastic limestones and travertine were identified in walls 4 and 5 as well, belonging to the middle-second half of fourteenth century/second Gothic reconstruction, the eleventh century/ÁRPÁD reconstruction and the intervention that took place in
2005. Rhyolite was also widely used in some construction phases (e.g. wall 2-end of fifteenth century/King Matthias expansion, and wall 3-twelfth century/ ÁRPÁD reconstruction). The use of granite in the last construction phase was also remarkable (wall 2-end of fifteenth century/King Matthias expansion).

Several weathering forms were observed on the various lithotypes of the monument and they mapped for the case of the five selected wall sections (Theodoridou 2009). The most severe weathering processes occurred on the oolitic limestone when compared to the other lithotypes of the monument. Individual fissures visible by naked eye were observed (e.g. wall 1 (Fig. 5) and wall 2). Detachment of grains also occurred, such as crumbling and granular disintegration (e.g. wall 1 (Fig. 5), walls 2 and 3). Further detachment of thin layers of, in general, a millimetric scale (multiple scaling) could be

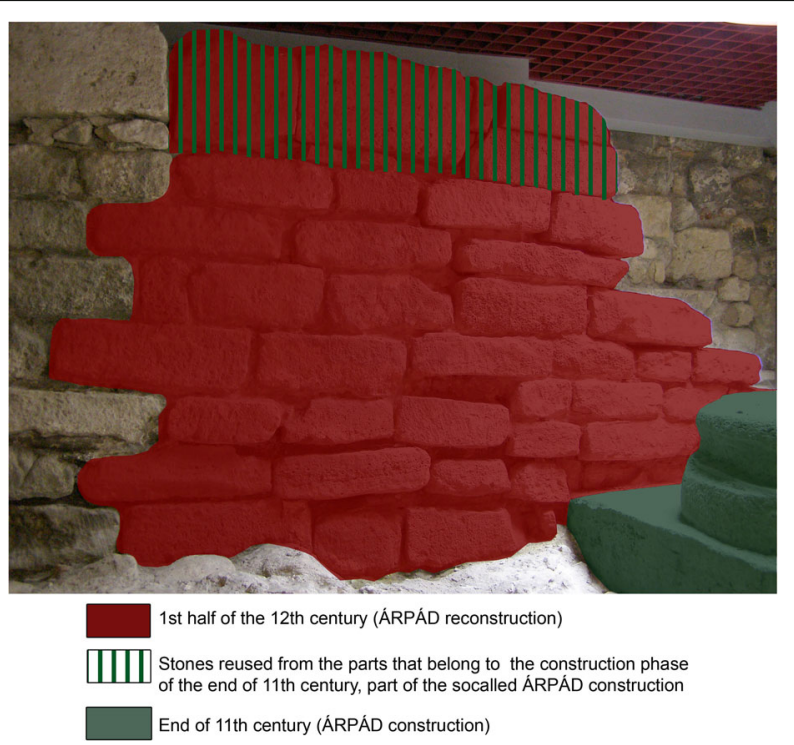

Fig. 3 Wall 1-Map of construction phases 


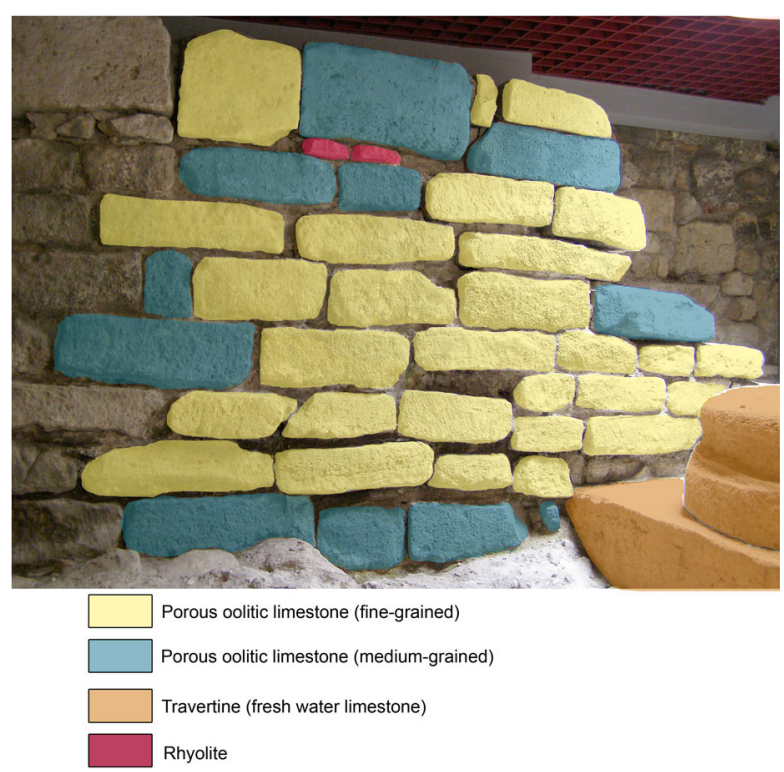

Fig. 4 Wall 1-Map of lithotypes

seen, for instance on the blocks of oolitic limestone of wall 4. Exogenic deposits in combination with materials derived from the stone created black and white crust in different blocks of the aforementioned lithotype (e.g. wall 1 (Fig. 5) and wall 4). Detachment of the black crust was observed in the case of fine-grained oolitic limestone (e.g. wall 1 (Fig. 5)).

In the case of bioclastic limestone, minor cracks were noted with a dimension smaller than $0.1 \mathrm{~mm}$, the so-called hair-line cracks, crumbling and erosion that leads to smoother shapes due to loss of material such as rounding and roughening of the surfaces (e.g. wall 3). In the case of blocks of bioclastic limestone totally exposed to the exterior environment (e.g. wall 2), black crust and biological colonisation (moss, lichens and plants) were also observed.

The same forms of biological colonisation were observed on the blocks of travertine which were exposed to the outdoor environmental conditions, as well as crack formation (e.g. wall 5). Besides the pre-existing pore system networks of small interconnected depressions of millimetre to centimetre scale, dissolution

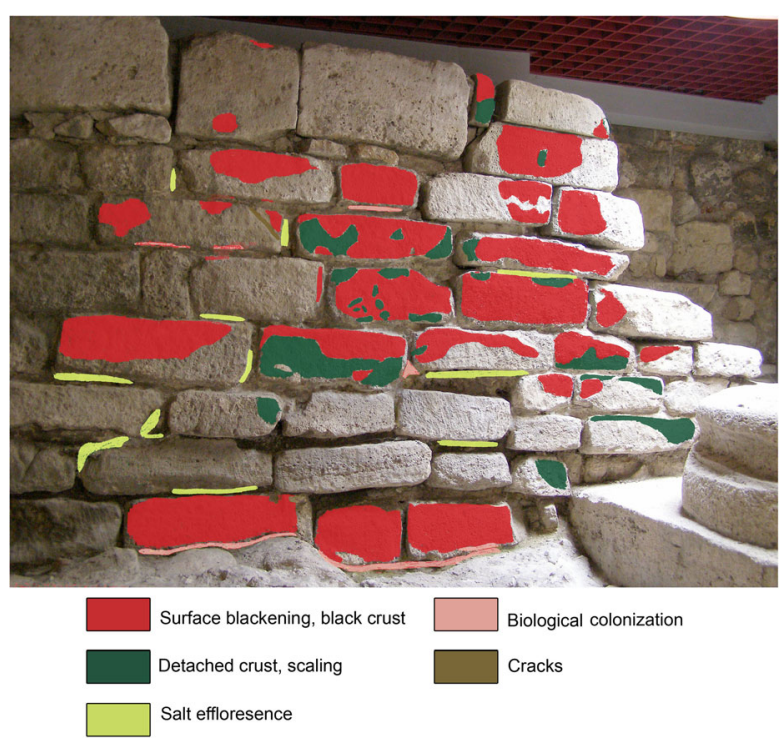

Fig. 5 Wall 1-Map of weathering forms 
features were also observed on the exposed travertine. The latter decay form was a result of surface dissolution from exposure to water run-off.

The red limestone appeared to be the most durable among the different types of limestones. Only minor alterations were observed on these blocks, such as decolourization of the surface (e.g. wall 3) and a few cracks.

In some cases of granitic blocks exposed to the environmental conditions (e.g. wall 2), major cracks and multiple flaking (scaling in thin scales of millimetric thickness) occurred. Rhyolite seemed to be relatively resistant to weathering processes besides a few hair-line cracks observed in relatively small blocks (e.g. wall 3).

Additionally, salt efflorescence (e.g. wall 1 (Fig. 5)) and biological colonisation were observed on the historical mortar of the ruins. Especially the latter one was intense in the areas that were close to the ground level (e.g. wall 1 (Fig. 5), walls 3 and 4). In a few cases, the presence of algae expanded to the adjacent blocks of rhyolite (e.g. wall 2) and travertine (e.g. wall 4).

\section{Schmidt hammer and Gann Hydromette}

The Schmidt hammer values and the moisture content measured on the blocks of the selected walls were depicted on the maps of lithotypes. Figure 6 shows the representative example of wall 1 . The Schmidt hammer values were recorded higher for the more compact stones, such as rhyolite and granite, with the red limestone performing also relatively high rebound values. Most types of limestones performed relatively low values, with the oolitic showing generally lower values than the travertine.
The moisture content values were also presented on the same maps (e.g. Fig. 6). The fluctuation of the values for the same lithotype was related to the influence of the different environmental conditions on the stone materials; blocks of the same lithotype showed higher moisture values where they were located in shadow areas, especially in the covered parts of the monument. For instance, in the case of wall 1 (Fig. 6), the blocks which were on the right part of the wall, where the sunlight passes through a transparent glass located on the right top of the ceiling, were associated with lower moisture content values than the blocks that had constantly been under shadow. Moreover, in all cases, the blocks located closer to the ground had higher moisture content than blocks of the same lithotype which were located at a higher distance from the ground level.

\section{Drilling resistance}

Three drilling measurements were carried out on each block with an exception of the quartz-porphyry rhyolite, where the measurement could not be completed due to its higher drilling resistance than the potential of the measuring system. Profiles showing the average values of the demanded drilling forces versus the drilled depth from the surface to the interior of the material are given in Figs. 7 and 8. Looking at the profiles of different blocks of oolitic limestone (Fig. 7) and in particular to the one belonging to the block that was exposed to the exterior environmental conditions (block 27), the highest drilling resistance was observed at approximately the first $1.5 \mathrm{~mm}$ of the drilling depth which was followed by lower values measured in the interior part of the

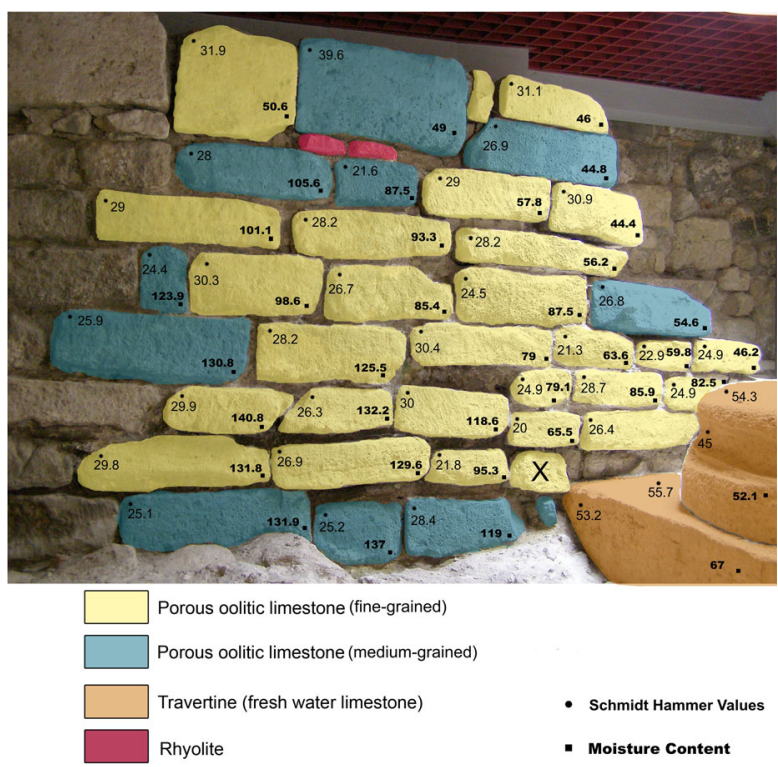

Fig. 6 Wall 1-Schmidt hammer and moisture content values 

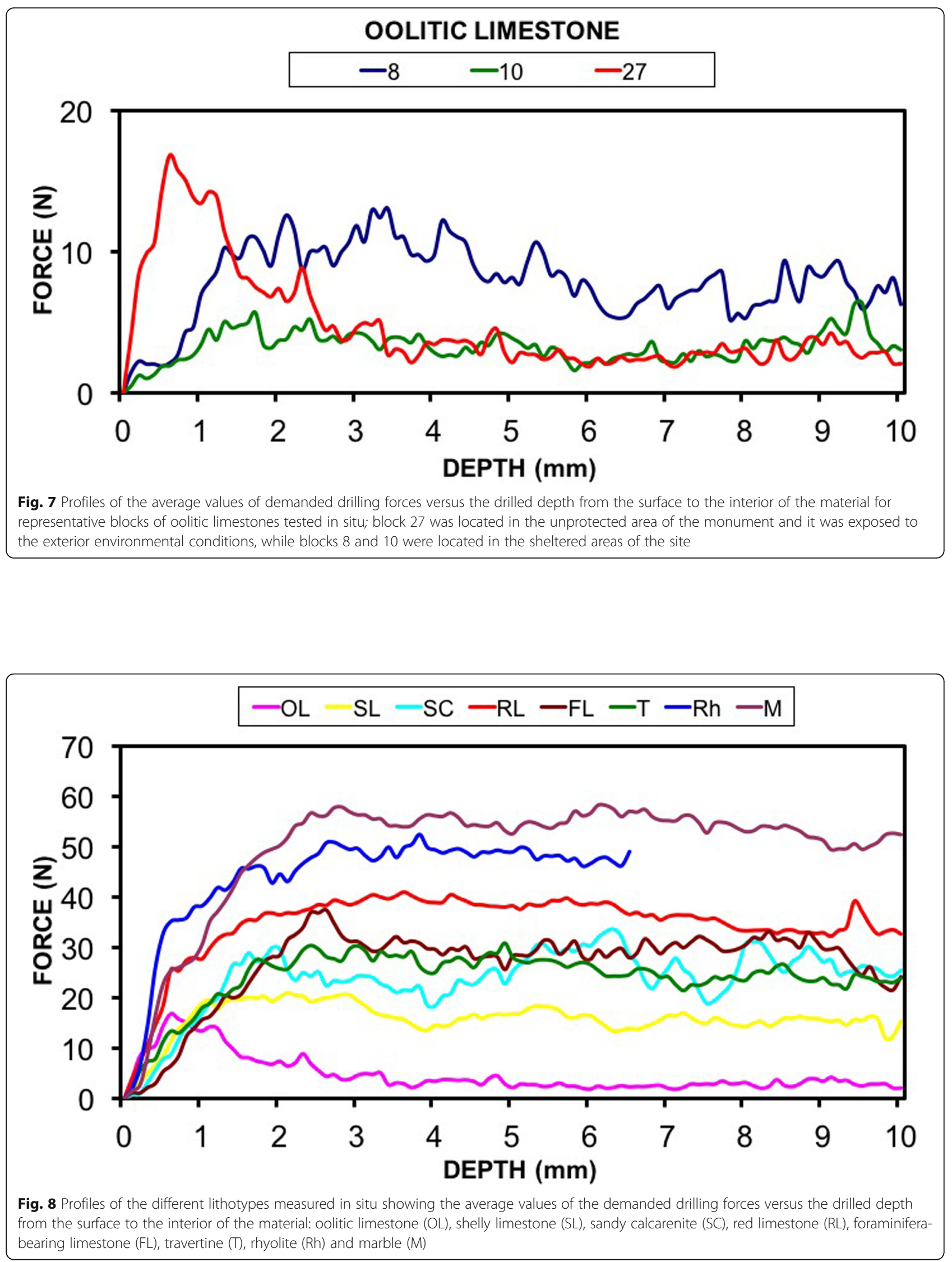
material. This was not the same for the oolitic limestone located in the protected areas of the monument (blocks 8 and 10). The profiles of the shelly limestone, sandy calcarenite and red limestone (Fig. 8) showed an increase in the drilling resistance during the approximately topmost $2 \mathrm{~mm}$.

\section{Discussion}

Limestone was the most common building stone found in the historic structures at the Székesfehérvár Ruin Garden. From a variety of limestone lithotypes, the oolitic limestone (OL) was the prevailing one, while the use of other types, such as shelly limestone (SL) and red compact limestone (RL), was also remarkable (Table 1). Additionally, several blocks of other lithologies, such as sandy calcarenite $(\mathrm{SC})$, rhyolite $(\mathrm{Rh})$, marble $(\mathrm{M})$, travertine (T) and other types of fossiliferous limestones (FL) were identified (Table 1). Regarding the use of different stone types, there was a clear distinction between the several construction phases. OL was used throughout the entire history of the construction (wall 1 (Figs. 3 and 4 ), walls $2-5$ ), while RL appeared only in the reconstruction period, that took place in the twelfth century (wall 3 ). This observation is in good correlation with the previous findings (Kertész and Szabó-Balog 1988), since the use of RL in Hungarian monuments dating back to twelfth to eighteenth centuries was relatively common (Pintér et al. 2004; Török 2007a). The RL, which is analogous to the Italian Rosso di Ammonitico, was a popular dimension stone not only in Hungary, but throughout the Mediterranean Basin (Lazzarini 2004). In Central Europe, quarries of red limestones are known not only from Hungary, but also from Austria (e.g. Adnet) and from Romania (Pintér et al. 2004). The oolitic limestone (OL), or better defined as porous limestone, is also widespread in other monuments in Hungary (Kertész 1982) but it includes varieties of lithologies (Török 2004a). The so-called Leitha Limestone, which is a Miocene porous limestone type, is known from Austria, Czech Republic and Hungary (Török 2004a). In Hungary, several porous limestone lithotypes are known and historic quarries that could have provided the stone for Székesfehérvár can be found in the vicinity (Öskü) or at a distance of few tens of kilometres from the Ruin Garden (Budapest, or Fertırákos) (Török 2004a). Based on micro-fabric analyses, it is very probable that oolitic limestone (OL), which was used at Székesfehérvár, was quarried in Budapest region (probably at Sóskút area) (Török 2002), while shelly limestone (SL) and sandy calcarenite (SC) came from Öskü area (Török 2004a). At the latter locality, no more active quarries exist and the former ones are abandoned and often difficult to identify, which hampers the provenance analyses. The provenance of the other stones used at
Székesfehérvár is very likely to be found in the present territory of Hungary, except for the case of marble. The travertine was from the North, from Süttő area (see Kertész 1982; Török 2007a) and the red limestone from Tardos (Kertész 1982; Pintér et al. 2004). The rhyolite (RH) was most likely from the nearby igneous area of Velence Mountains, but at present, no similar volcanic stones are exposed in quarries. The marble (M) most probably came from other territories than the current territory of the modern Hungarian state, but further studies, such as geochemical analyses, would be needed to identify the exact provenance.

The long-term behaviour of stone structures depends on the durability of the stone materials (Macmillan 1967; Kieslinger 1968; Richardson 1991; Ordóñez et al. 1997; Vázquez et al. 2016; Přikryl et al. 2016; Prrikryl 2017), vegetation cover (Coombes et al. 2018) and the environmental conditions (Amoroso and Fassina 1983; Siegesmund et al. 2007). When the various lithotypes of the studied Ruin Garden were compared it seemed that oolitic limestone (OL), which was the most common one, was less durable than other lithologies found at the site. Based on the in situ observation, OL displayed various forms of decay such as cracks, crumbling, granular disintegration, multiple scaling and flaking, black and white crust and biological colonisation (wall 1 (Fig. 5), walls $2-5$ ). The bioclastic limestone also showed several decay forms, such as micro-cracks, crumbling, rounded surface, black crust and, in the case of blocks totally exposed to the exterior environment (wall 2), biological colonisation was also observed. The same forms of biological colonisation were observed on the blocks of travertine, which were exposed to the outdoor environmental conditions, in addition to cracks and micro-karstification (wall 4). Biological colonisation was not restricted to outdoor environments. At the covered parts of the ruin, green patches of microbial mats were observed (wall 1 (Fig. 5), walls 3-4). This was especially intense at low-lying blocks and in the joints, suggesting that capillary water rise of groundwater provided moisture for biological activity. A clear dependence on the substrate was also noticed, since porous stone types, such as OL, were preferentially covered, while lower porosity stones, such as travertine $(\mathrm{T})$ or rhyolite $(\mathrm{Rh})$, showed far less intense biological colonisation (walls 34). Among the different types of limestones, the red limestone appeared to be the most durable one, since only minor alterations were observed, such as decolourization of the surface (wall 3). Stylolitic planes were also observed in the red limestone and, as was shown previously (Aly et al. 2018), these clay-containing zones were prone to weathering. In some cases, cracks and multiple flaking developed even on blocks of relatively durable stone types, such as granitic blocks in the uncovered 
parts of the monument, which were exposed to the environmental conditions (wall 2).

Rhyolite (Rh) also seemed to be relatively resistant to decay; besides a few micro-cracks, no major decay forms were observed on the relevant blocks (wall 3). Former studies showed similar behaviour when those materials were used in historical structures in other locations of the country (Kertész 1988; Török 2003, 2006, 2007b; Török et al. 2007a, 2007b; Török et al. 2011; Bögöly et al. 2015).

The stone decay and especially the deterioration of limestone monuments is a commonly reported phenomenon from other countries, too. It is caused either by environmental conditions, such as freeze-thaw or thermal stresses or by pollution plumes. The air pollution-related soiling have been reported from cities with heavy traffic load such as Athens (Moropoulou et al. 1998), London (Trudgill et al. 1991; Bonazza et al. 2007) or Budapest (Török 2002, 2004b). Exposed limestone facades located in smaller urban areas with heavy pollution fluxes also show intense blackening in cities such as Venice (Amoroso and Fassina 1983; Sabbioni 1995), Oxford (Viles 1993; Smith and Viles 2006) or in other cities (La Russa et al. 2017; Pozo-Antonio et al. 2017; Gibeaux et al. 2018). At Székesfehérvár, the local transport related pollution is less intense and the Ruin Garden is located in a pedestrian area; therefore, gypsum-rich black crust formation was subordinate. The major decay processes were related to climatic conditions. The annual 70-75 freeze-thaw cycles were responsible for the granular disintegration of porous limestones $(\mathrm{OL})$, as well as for scaling and flaking. Similar processes of porous limestone decay and frost damages were also reported from Budapest (Török 2002, 2003, Török and Rozgonyi 2004, Török et al. 2007b). Porous limestones that are found in other parts of the world are also prone to weathering (Cassar 2002; Vázquez et al. 2016), and it has been documented that water absorption and frost (Al-Omari et al. 2015; Hassine et al. 2018) can lead to rapid decay. Micro-cracks and micro-fractures observed on other lithologies were also related to freeze-thaw. Therefore, the new roof could be beneficial in terms of regulating climatic conditions and reducing frost damage at the Ruin Garden. Salt-related decay, which is common in maritime environments, was not observed under the continental climate of Székesfehérvár. The use of de-icing salts has not been a common practice at the monument; therefore, minor salt efflorescence observed at some blocks is very probably related to the use of cement mortar as repair materials in the 1960s.

Non- and micro-destructive techniques were selected for the estimation of the materials' strength in situ, as they are more suitable for heritage structures where sampling is limited. More specifically, micro-drilling resistance and
Schmidt hammer tests were performed at the Székesfehérvár Ruin Garden.

In the current research, the average demanded drilling forces gave a good estimation of the strength parameters of the tested materials, which agree well with the literature (e.g. Theodoridou et al. 2015, Exadaktylos et al. 2000, Tiano et al. 2000, Delgado Rodrigues et al. 2002, Pamplona et al. 2008, Vázquez et al. 2016). The drilling profiles corresponded to the microfabric of the materials close to the surface, e.g. higher heterogeneity for the sandy calcarenite due to the presence of quartz grains in comparison with the compact red limestone (Fig. 8). Moreover, the results achieved by in situ measurements depicted the occurring weathering phenomena, such as the presence of crust on the surface of oolitic limestone by showing higher drilling resistance on the topmost millimetre (Fig. 7, block 27). At greater depth, the samples showed lower values (Figs. 7 and 8).

Drawbacks of the micro-drilling technique have been already mentioned along with relevant suggested solutions, such as the influence of using different drill bits in situ (Tiano et al. 2000; Pamplona et al. 2007), the dust accumulation during drilling (Mimoso and Costa 2006), the virtual increase of drilling resistance in case of abrasive stones (Pfefferkorn 2000, Singer et al. 2000, Delgado Rodrigues and Costa 2004) and the problem in drilling hard materials due to the limitation of the drilling system (maximum measurable drilling force equal to $100 \mathrm{~N}$ ). The latter was the reason in this study micro-drilling could not be performed on rhyolite (Fig. 8). However, possible solutions to this issue have been already published (e.g. Mimoso and Costa 2008; Pamplona et al. 2008).

Regarding the Schmidt hammer application (e.g. Fig. 6), the results contributed to a quick and non-destructive estimation of the materials strength properties. Furthermore, weathering of the materials surfaces could be detected by the changes in surface strengths measured by the method as, for instance, the increase in surface strength due to the formation of weathering crusts. This decay pattern of oolitic limestone was also recorded in previous studies (Török 2003). It should be also clarified that despite the fact that the technique is considered a non-destructive one, small impound marks are produced on the surface of tested stones. Hence, the application of the test was avoided on deeply weathered stone blocks.

The moisture content of the stone blocks in situ is one of the most crucial factors for the long-term behaviour of stones (Török 2009). Several methods are known for measuring this value, such as conductometry and thermographic imagery (Meinhardt-Degen et al. 2008), field dielectometry and unilateral nuclear magnetic resonance (Olmi et al. 2008). However, the high costs of applying some of the aforementioned techniques in situ might be an obstacle. In our case, the Gann Hydromette Uni was used, which, despite the fact that it gives only 
relative and not absolute values, can give a profile of the different values in different measured points. The achieved measurements (e.g. Fig. 6) presented a good indicator of the influence of climatic conditions for each block, e.g. higher moisture content values for the same lithotype in case of blocks located closer to the ground or in areas that were constantly in shadow. It has been documented that water uptake can influence the durability of porous limestones (Török et al. 2007a; Vázquez et al. 2016; Hassine et al. 2018), and thus, it is also linked with the intensity of frost damage (Al-Omari et al. 2015). Water and moisture content controls the durability of travertine, too (Török and Vásárhelyi 2010). Many of the measured points with higher moisture content values had already presented salt efflorescence and/or biological colonisation. Therefore, the use of this low-cost technique could contribute significantly to the identification of endangered zones.

\section{Conclusions}

The mapping method presented in this paper proved to be very useful for the identification of the site, such as the documentation of the different lithotypes used over the different construction periods, the record of the in situ measured values and their ensuing interpretation in relation with the existing climatic conditions and the correlation of the identified weathering forms with the different lithotypes.

The use of several lithotypes, such as different kinds of limestone, rhyolite and granite, was identified in the Ruin Garden of Székesfehérvár throughout its several construction periods between the eleventh and the fifteenth century. Few blocks of marble whose origin was most probably out of the borders of the Carpathian Basin were also found. Oolitic limestone was found the prevailing type among the different types of limestones used in the several construction periods of the monument, which is in accordance with its generally wide use in historic constructions in the region. Moreover, the red limestone, which was found in the part that was constructed in the twelfth century and is very similar to the Italian Rosso di Ammonitico, is another popular dimension stone in monumental constructions. Both of the aforementioned materials could be found in Hungarian quarries, which are very close to the location of the studied site such as the quarry in Sóskút which provides oolitic limestone and the quarry in Tardos for the red limestone.

In situ observations suggest that oolitic limestone suffered the most in terms of weathering since several decay patterns were identified, such as black crust, scaling, crumbling, flaking, granular disintegration, rounded surfaces and biological colonisation. This weathering susceptibility is related to the micro-fabric, i.e. high porosity of the lithotype. Red limestone seemed to be relatively durable with decolourization of the surface being its main observed weathering form together with dissolution along stylolites. Those results were in accordance with the results of the in situ measurements by means of Schmidt hammer and micro-drilling. Moisture content measurements proved the influence of micro-environmental conditions on the stones seeing that higher values coincided with more intense decay forms, as for instance in the case of biological colonisation.

All in situ test results were found consistent with the physical state of the stone materials and the identified decay forms on their surface. Thus, those non- or micro-destructive tests could contribute significantly to the characterisation of the materials and the identification of endangered zones at heritage sites, where sampling is limited, preventing or delaying further decay.

Regarding the importance of the presented research in relation with the conservation of the studied site, the in situ investigation provided an overview of the state of conservation of the stones of the Ruin Garden prior to the construction of a new roof system. Also, the results will keep serving as a database in the long term for the future comparison of the stones' behaviour before and after the reconstruction of the site.

\section{Acknowledgements \\ Dr. Biczó Piroska from the Hungarian National Museum is very much appreciated for her help in accessing the heritage site and the documentation of its construction history. Dr. Piero Tiano, Dr. Susanna Bracci and Dr. Barbara Sacci from the ICVBC in Florence are thanked for representing MOLAB in Hungary and supporting the performance of DRMS in situ. MT would like to thank Dr. Sándor Józsa for his support from the side of Eötvös Loránd University during the EPISCON project, as well as Dr. Szakmány György for his assistance. \\ The authors gratefully acknowledge the travel grant from Japan Geoscience Union to attend the Japan Geosciences Union Meeting 2017 that took place in Tokyo, Japan.}

\section{Funding}

This project was part of the EPISCON project and financially supported by the Marie Curie Actions (6th Framework Programme's Human Resources and Mobility - HRM, European Union). The application of the DRMS in situ was part of the Mobile LABoratory-MOLAB of the Eu-Artech project funded under the 6th Framework Programme's Infractures-1.

The financial support of National Research, Development and Innovation (NKFI) Fund (ref. no. K 116532) and BME FIKP-VÍZ by EMMI to ÁT are appreciated.

\section{Availability of data and materials}

This work contains data of an ongoing project. Please contact authors for data requests.

Authors' contributions

Both authors contributed equally to the paper. Both authors read and approved the final manuscript.

Competing interests

The authors declare that they have no competing interest. 


\section{Publisher's Note}

Springer Nature remains neutral with regard to jurisdictional claims in published maps and institutional affiliations.

\section{Author details}

${ }^{1}$ Cardiff School of Engineering, Cardiff University, Queen's Buildings, The Parade, Cardiff, Wales CF24 3AA, UK. 'Department of Engineering Geology and Geotechnics, Budapest University of Technology and Economics, Müegyetem rkp. 3, Building K, Budapest H-1111, Hungary.

Received: 23 April 2018 Accepted: 27 January 2019

Published online: 13 February 2019

\section{References}

Al-Omari A, Beck K, Brunetaud X, Török Á, Al-Mukhtar M (2015) Critical degree of saturation: a control factor of freeze-thaw damage of porous limestones at Castle of Chambord, France. Eng Geol 185:71-80

Altmann J, Biczó P, Buzás G, Horváth I, Kovács A, Siklósi G, Végh A (1999) Medium Regni. Nap Kiadó, Budapest 212p

Aly N, Wangler T, Török Á (2018) The effect of stylolites on the deterioration of limestone: possible mechanisms of damage evolution. Environ Earth Sci 77: 565 (https://doi.org/10.1007/s12665-018-7746-2)

Amoroso GG, Fassina V (1983) Stone decay and conservation. Elsevier, Amsterdam 453p

Barton N, Choubey V (1977) The shear strength of rock joints in theory and practice. Rock Mech Rock Eng 10:1-54

Bartos G, Biczó P, Buzás G, Livei Lővei P, Mentényi K, Tóth M (2004) The provostry and church of the Virgin Mary. King St. Stephen Museum, Székesfehérvár 44p

Beck K, Al-Mukhtar M (2008) Formulation and characterization of an appropriate lime-based mortar for use with a porous limestone. Environ Geol 56(3-4): 715-727

Bell FG (1993) Durability of carbonate rock as a building stone with comments on its preservation. Environ Geol 21:187-200

Biczó P (2005) Székesfehérvár. Nemzeti Emlékhely I-II. [The Székesfehérvár National Monument I-II]. Tájak-Korok-Múzeumok Kiskönyvtára 309-310 szám. TKM Egyesület. (in Hungarian)

Bögöly G, Török Á, Görög P (2015) Dimension stones of the North Hungarian masonry arch bridges. Cent Eur Geol 58:230-245

Bonazza A, Brimblecombe P, Grossi C, Sabbioni C (2007) Carbon in black crusts from the Tower of London. Environ Sci Technol 41(12):4199-4204

Bonazza A, Sabbioni C, Ghedini N (2005) Quantitative data on carbon fractions in interpretation of black crusts and soiling on European built heritage. Atmos Environ 39:2607-2618

Brimblecombe P, Grossi CM (2009) Millennium-long damage to building materials in London. Sci Total Environ 407:1354-1361

Calparsoro E, Maguregui M, Giakoumaki A, Morillas H, Madariaga JM (2017) Evaluation of black crust formation and soiling process on historical buildings from the Bilbao metropolitan area (north of Spain) using SEM-EDS and Raman microscopy. Environ Sci Pollut Res Int 24:9468-9480

Camuffo D (1998) Microclimate for cultural heritage. Elsevier, Amsterdam 432p

Cassar JA (2002) Deterioration of the Globigerina limestone of the Maltese Islands. In: Siegesmund S, Weiss TS, Vollbrecht A (eds) Natural Stones, weathering phenomena, conservation strategies and case studies, vol 205. Geological Society, Special Publications, London, pp 33-49

Christaras B (1996) Non destructive methods for investigation of some mechanical properties of natural stones in the protection of monuments. Bull Int Assoc Eng Geol 54:59-63

Cnudde V, Silversmit G, Boone M, Dewanckele J, de Samber B, Schoonjans T, Van Loo D, de Witte Y, Elburg M, Vincze L, van Hoorebeke L, Jacobs P (2008) Multidisciplinary characterisation of a sandstone surface crust. Sci Total Environ 407:5417-5427

Coombes M, Viles HA, Zhang H (2018) Thermal blanketing by ivy (Hedera helix L.) can protect building stone from damaging frosts. Scientific Reports 8 . https:// doi.org/10.1038/s41598-018-28276-2

De Kock T, Van Stappen J, Fronteau G, Boone M, De Boever W, Dagrain F, Silversmit G, Vincze L, Cnudde V (2017) Laminar gypsum crust on lede stone: Microspatial characterization and laboratory acid weathering. Talanta 162: 193-202

Delgado Rodrigues J, Costa D (2004) A new method for data correction in drilling resistance. Tests for the effect of drill bit wear. Int J Restoration Build Monuments 10:1-18
Delgado Rodrigues J, Ferreira Pinto A, Rodrigues da Costa D (2002) Tracing of decay profiles and evaluation of stone treatments by means of microdrilling techniques. J Cult Herit 3:117-125

Drury M (2006) Restoration versus Conservation. In: Henry A, Pearce J (eds) Stone conservation principles and practice. Donhead, Dorset, pp 33-56

Exadaktylos G, Tiano P, Filareto C (2000) Validation of a model of rotary drilling of rocks with the drilling force measurement. Int J Restoration Build Monuments 3:307-340

Fitzner B, Heinrichs K (2002) Damage diagnosis on stone monuments weathering forms, damage categories and damage indices. In: Prikryl R, Viles HA (eds) Understanding and managing stone decay, Proceeding of the International Conference Stone weathering and atmospheric pollution network (SWAPNET 2001). The Karolinum Press, Charles University in Prague, pp 11-56

Fitzner B, Heinrichs K, Kownatzki R (1995) Weathering forms classification and mapping. Verwitterungsformen - Klassifizierung und Kartierung. In: Denkmalpflege und Naturwissenschaft, Natursteinkonservierung I. Förderprojekt des Bundesministeriums für Bildung, Wissenschaft, Forschung und Technologie, Verlag Ernst \& Sohn, Berlin, pp 41-88

Fitzner B, Heinrichs K, Kownatzki R (1997) Weathering forms at natural stone monuments - classification, mapping and evaluation. Int J Restoration Build Monuments 3(2):105-124

Fitzner B, Heinrichs K, La Bouchardiere D (2002) Damage index for stone monuments. In: Galan E, Zezza F (eds) Protection and conservation of the cultural heritage of the Mediterranean cities. Proceedings of the 5th International Symposium on the Conservation of Monuments in the Mediterranean Basin, Sevilla, Swets \& Zeitlinger, Lisse, pp 315-332

Fort R, Alvarez de Buergo M, Perez-Monserrat E, Varas MJ (2010) Characterisation of monzogranitic batholiths as a supply source for heritage construction in the northwest of Madrid. Eng Geol 115:149-157. https://doi.org/10.1016/j. enggeo.2009.09.001

Gibeaux S, Vázquez P, De Kock T, Cnudde V, Céline Thomachot-Schneider C (2018) Weathering assessment under $X$-ray tomography of building stones exposed to acid atmospheres at current pollution rate. Construct Build Mater 168:187-198

Graue B, Siegesmund S, Oyhantcabal P, Naumann R, Licha T, Simon K (2013) The effect of air pollution on stone decay: the decay of the Drachenfels trachyte in industrial, urban, and rural environments - a case study of the Cologne, Altenberg and Xanten cathedrals. Environ Earth Sci 69:1095-1124

Hassine MA, Beck K, Brunetaud X, Al-Mukhtar M (2018) Strain measurements during capillary water infiltration in porous limestones. Construct Build Mater 175:439-447

ICOMOS-ISCS (2008) In: Vergès-Belmin V (ed) Illustrated glossary on stone deterioration patterns / Glossaire illustré sur les formes d'altération de la pierre. Ateliers 30 Impression, Champigny/Marne 78p

Jokilehto J (1999) A history of architectural conservation. Elsevier, Oxford

Kahraman S (2001) Evaluation of simple methods for assessing the uniaxial compressive strength of rock. Int J Rock Mech Min Sci 38:981-994

Katz O, Reches Z, Roegiers JC (2000) Evaluation of mechanical rock properties using a Schmidt hammer. Int J Rock Mech Min Sci 37:723-728

Kertész P (1982) A mőemléki kıanyagok bányahelyeinek kutatása. Építés- és Építészettudomány (Research of mounumental stones and historic quarries), vol 1-2, pp 193-228 (in Hungarian)

Kertész P (1988) Decay and conservation of Hungarian building stones. In: Marinos PG, Koukis GC (eds) The engineering geology of ancient works, monuments and historical sites, vol 2. IEAG Conference Proceedings, Athens, pp 755-761 Rotterdam (Balkema)

Kertész P, Szabó-Balog A (1988) Provenance and petrographical problems of the building and ornamental stone materials of Hungarian Renaissance architecture. Period Polytech 32(3-4):169-193

Kieslinger A (1968) Les principaux facteurs des pierres à bâtir. ICOMOS Monum 11:61-65 (in French)

Kusar D (2008) The impact of natural disasters on buildings' architectural styles. Acta Geogr Slov 48:93-120

La Russa MF, Fermo P, Comite V, Belfiore CM, Barca D, Cerioni A, De Santis M, Barbagallo LF, Ricca M, Ruffolo SA (2017) The Oceanus statue of the Fontana di Trevi (Rome): the analysis of black crust as a tool to investigate the urban air pollution and its impact on the stone degradation. Sci Total Environ 593594:297-309

Lazzarini L (ed) (2004) Pietre e Marmi Antichi. CEDAM, Castenaso (Bologna) Macmillan M (1967) La gélivité des materiaux. Suppl Ann Inst Tech Bâtim Trav Publics 6:1017-1024 (in French) 
Mahgoub Y (2008) The impact of war on the meaning of architecture in Kuwait. Archnet-IJAR. Int J Archit Res 2:234-246

Maravelaki-Kalaitzaki P, Biscontin G (1999) Origin, characteristics and morphology of weathering crusts on Istria stone in Venice. Atmos Environ 33:1699-1709

McAlister JJ, Smith BJ, Török Á (2008) Transition metals and water-soluble ions in deposits on a building and their potential catalysis of stone decay. Atmos Environ 42:7657-7668

Meinhardt-Degen J, Franzen C, Löther T, Weise S (2008) In: Lukaszewicz J, Niemcewicz P (eds) Application of active infrared thermography for the detection of sub-surface detects in historic wall paintings and the assessment of their backfilling, vol 1. Proceedings of the 11th International congress on deterioration and Conservation of Stone, ICOMOS Poland, Torun, pp 441-448

Miller RP (1965) Engineering classification and index properties for intact rock. PhD Thesis, University of Illinois

Mimoso J, Costa D (2006) The DRMS drilling technique with pilot holes. In: Proceedings of the International Heritage, Weathering \& Conservation Conference. Consejo Superior de Investigaciones Cientificas, Madrid, pp $651-656$

Mimoso J, Costa D (2008) A new technique for using DRMS in hard materials. Application to the study of the consolidation action. In: Delgado Rodrigues C, Mimoso JM (eds) Proceedings of the International Symposium for Stone consolidation in cultural heritage - research and practice. LNEC, Lisbon, pp 359-368

Modestou S, Theodoridou M, Fournari R, loannou I (2016) Physico-mechanical properties and durability performance of natural building and decorative carbonate stones from Cyprus. In: Pr̈̈kryl R, Török Á, Gómez-Heras M, Miskovsky K, Theodoridou M (eds) Sustainable use of traditional geomaterials in construction practice, vol 416. Geological Society, Special Publications, London, pp 145-163

Modestou S, Theodoridou M, loannou I (2015) Micro-destructive mapping of the salt crystallization front in limestone. Eng Geol 193:337-347

Moropoulou A, Bisbikou K, Torfs K, Van Grieken R, Zezza F, Macri F (1998) Origin and growth of weathering crusts on ancient marbles in industrial atmosphere. Atmos Environ 32:967-982

Olmi R, Riminesi C, Priori S, Proietti N, Capitani D, Segre AL, Giani E, Santopadre P (2008) An integrated approach to mapping moisture and salt content in two frescoes in the Basilica of San Clemente. In: Tiano P, Pardini C (eds) In situ monitoring of monumental surfaces. Edifir-Editzioni, Florence, pp 239-246

Ordóñez S, Fort R, García del Cura MA (1997) Pore size distribution and the durability of a porous limestone. Q J Eng Geol 30:221-230

Pamplona M, Kocher M, Snethlage R (2008) Micro drilling reseistance - how can satisfying correlations with mechanical properties be found? In: Tiano P, Pardini C (eds) In situ Monitoring of Monumental Surfaces. Edifir-Editzioni, Florence, pp 341-346

Pamplona M, Kocher M, Snethlage R, Aires-Barros L (2007) Drilling resistance: overview and outlook. Z Dtsch Ges Geowiss 158(3):665-676

Pappalardo G, Mineo S, Monaco C (2016) Geotechnical characterization of limestones employed for the reconstruction of a UNESCO world heritage Baroque monument in southeastern Sicily (Italy). Eng Geol 212:86-97

Pfefferkorn S (2000) Correction functions for eliminating drill bit abrasion and blocked drill dust transport. In: Tiano P (ed) Proceedings of the Workshop DRILLMORE - drilling methodologies for monuments restoration. Centro Stampa Toscana Nuova, Firenze, pp 67-74

Pintér F, Szakmány G, Demény AA, Tóth M (2004) The provenance of "red marble" monuments from the 12th - 18th centuries in Hungary. Eur J Mineral 16:619-629

Pozo-Antonio JS, Pereira MFC, Rocha CSA (2017) Microscopic characterisation of black crust on different substrates. Sci Total Environ 584-585:291-306

Prikryl R (2007) Understanding the Earth scientist's role in the pre-restoration research of monuments: an overview. In: Prikikryl R, Smith BJ (eds) Building stone decay: from diagnosis to conservation, vol 271. Geological Society, Special Publications, London, pp 9-21

Prikkryl R (2013) Durability assessment of natural stone. Q J Eng Geol Hydrogeol 46:377-390

Prikkryl R (2017) Constructional geomaterials: versatile earth resources in the service of humankind-introduction to the thematic set of papers on: challenges to supply and quality of geomaterials used in construction. Bull Eng Geol Environ 76:1-9

Prïkryl R, Török Á, Theodoridou M, Gomez-Heras M, Miskovsky K (2016) Geomaterials in construction and their sustainability: understanding their role in modern society. In: Prikrryl R, Török A, Gomez-Heras M, Miskovsky K, Theodoridou M (eds) Sustainable use of traditional geomaterials in construction practice, vol 416. Geological Society, Special Publication, London, pp 1-22

Richardson BA (1991) The durability of porous stones. Stone Ind 12:22-25

Sabbioni C (1995) Contribution of atmospheric deposition to the formation of damage layers. Sci Total Environ 167:49-55

Sachpazis Cl (1990) Correlating Schmidt hardness with compressive strength and Young's modulus of carbonate rocks. Bull Eng Geol Environ 42:75-83

Schaffer RJ (1932) The weathering of natural building stones. His Majesty's Stationary Office, London, p 149

Schmidt E (1951) A non-destructive concrete tester. Concrete 59(8):34-35

Siedel H (2010) Historic building stones and flooding: changes of physical properties due to water saturation. J Perform Constr Facil 24:452-461 https:// doi.org/10.1061/(ASCE)CF.1943-5509.0000066

Siegesmund S, Török Á, Hüpers A, Müller C, Klemm W (2007) Mineralogical, geochemical and microfabric evidences of gypsum crusts: a case study from Budapest. Environ Geol 52:358-397

Singer B, Hornschild I, Snethlage R (2000) Strength profiles and correction functions for abrasive stones. In: Tiano P (ed) Proceedings of the Workshop DRILLMORE - drilling methodologies for monuments restoration. Centro Stampa Toscana Nuova, Firenze, pp 35-42

Smith BJ, Viles HA (2006) In: Fort R, Alvarez de Buego M, Gomez-Heras M, Vazquez-Calvo C (eds) Rapid catastrophic decay of building limestones: thoughts on causes, effects and consequences, vol I. Heritage Weathering and Conservation, Taylor \& Francis/Balkema, London, pp 191-197

Theodoridou M (2009) Physical and mineralogical changes of Hungarian monumental stones exposed to different conditions: stone-testing in-situ and under laboratory conditions. PhD Thesis, University of Bologna

Theodoridou M, Dagrain F, loannou I (2015) Micro-destructive cutting techniques for the characterization of natural limestone. Int J Rock Mech Min Sci 76:98-103

Theodoridou M, loannou I (2015) Innovative applications of micro-destructive cutting techniques in the field of cultural heritage. In: DG Aggelis et al. (eds.) Emerging technologies in non-destructive testing VI, Brussels, Belgium 2729/5/2015. CRC Press Taylor \& Francis Group, London, 499-504

Tiano P (2001) In: Binda L, de Vekey RC (eds) The use of microdrilling techniques for the characterisation of stone materials, in Site control and non destructive evaluation of masonry structures and materials. (Rilem PRO26, 2003): Proceedings of the RILEM TC177 MDT International Workshop, Mantova, pp 203-214

Tiano P, Filareto C, Ponticelli S, Ferrari M, Valentini E (2000) Drilling force measurement system, a new standardisable methodology to determine the stone cohesion: prototype design and validation. Int Z Bauinstandsetzen Baudenkmalpflege, Geowissenschaften, Jahrgang, Heft 6(2):115-132

Török Á (2002) Oolitic limestone in polluted atmospheric environment in Budapest: weathering phenomena and alterations in physical properties. In: Siegesmund S, Weiss TS, Vollbrecht A (eds) Natural stones, weathering phenomena, conservation strategies and case studies, vol 205. Geological Society, Special Publications, London, pp 363-379

Török Á (2003) Surface strength and mineralogy of weathering crusts on limestone buildings in Budapest. Build Environ 38:1185-1192

Török Á (2004a) Leithakalk-type limestones in Hungary: an overview of lithologies and weathering features. In: Prikryl R, Siegel P (eds) Architectural and sculptural stone in cultural landscape. The Karolinum Press, Prague, pp 157-172

Török A (2004b) Comparison of the processes of decay of two limestones in a polluted urban environment. In: Mitchell DJ, Searle DE (eds) Stone deterioration in polluted urban environments. Science Publishers Inc, Enfield, pp 73-92

Török Á (2006) In: Fort R, Alvarez de Buergo M, Gómez-Heras M, Vasquez-Calvo C (eds) Hungarian travertine: weathering forms and durability. Heritage, Weathering and Conservation, London, pp 199-204

Török Á (2007a) Hungarian dimensional stones: an overview. Z Dtsch Ges Geowiss 158(3):361-374

Török Á (2007b) Morphology and detachment mechanism of weathering crusts of porous limestone in the urban environment of Budapest. Cent Eur Geol 50(3):225-240

Török Á (2008) Schmidt hammer and duroscope tests in assessing surface properties of stones. In: Tiano P, Pardini C (eds) In situ monitoring of monumental surfaces. Edifir- Editzioni, Florence, pp 207-214 
Török Á (2009) In situ methods of testing stone monuments and the application of non- destructive physical properties testing in masonry diagnosis. In: Dan $M B$ et al (eds) Materials, technologies and practice in historic heritage structures. Springer Science+Business Media BV, London, pp 177-193

Török Á, Forgó LZ, Vogt T, Löbens S, Siegesmund S, Weiss T (2007a) In: Prikryl R, Smith JB (eds) Differences in texture, physical properties and microbiology of weathering crust and host rock: a case study of the porous limestone of Budapest (Hungary), vol 271. Building Stone Decay: From Diagnosis to Conservation, Geological Society, Special Publications, London, pp 261-276

Török Á, Licha T, Simon K, Siegesmund S (2011) Urban and rural limestone weathering; the contribution of dust to black crust formation. Environ Earth Sci 63:675-693

Török Á, Prikrryl R (2010) Current methods and future trends in testing, durability analyses and provenance studies of natural stones used in historical monuments. Eng Geol 115(3-4):139-142. https://doi.org/10.1016/j.enggeo. 2010.07.003

Török Á, Rozgonyi N (2004) Mineralogy and morphology of salt crusts on porous limestone in urban environment. Environ Geol 46:333-349

Török Á, Stück H, Quetscher A, Glätzner P (2007b) Comparative study of weathering features of stones in Hungarian castles: morphological characteristics and changes in physical properties. Z Dtsch Ges Geowiss 158(4):931-955

Török Á, Vásárhelyi B (2010) The influence of fabric and water content on selected rock mechanical parameters of travertine, examples from Hungary. Eng Geol 115:237-245

Trudgill ST, Viles HA, Cooke RU, Inkpen RJ, Heathwaite LA, Houston J (1991) Trends in stone weathering and atmospheric pollution at St Paul's Cathedral, London, 1980-1990. Atmos Environ 25A(12):2851-2853

Vázquez P, Menéndez B, Denecker MFC, Thomachot-Schneider C (2016) Comparison between petrophysical properties, durability and use of two limestones of the Paris region. In: Prïkryl R, Török A, Gomez-Heras M, Miskovsky K, Theodoridou M (eds) Sustainable use of traditional geomaterials in construction practice, vol 416. Geological Society, Special Publications, London, pp 203-216

Viles H, Camuffo D, Fitz S, Fitzner B, Lindquist O, Livingston RA, Maravellaki PV, Sabbioni C, Warscheid T (1997) What is the state of our knowledge of the mechanisms of deterioration and how good are our estimations of rates of deterioration? In: Dahlem Workshop "Saving our architectural heritage - the conservation of historic stone structures". Wiley, UK, pp 95-112

Viles H, Goudie A, Grab S, Lalley J (2011) The use of the Schmidt Hammer and Equotip for rock hardness assessment in geomorphology and heritage science: a comparative analysis. Earth Surf Process Landf 36:320-333 https:// doi.org/10.1002/esp.2040

Viles HA (1993) The environmental sensitivity of blistering of limestones walls in Oxford, England: a preliminary study. In: Thomas DSG, Allison RJ (eds) Landscape sensitivity. Wiley, Chichester, pp 309-326

\section{Submit your manuscript to a SpringerOpen ${ }^{\circ}$ journal and benefit from:}

- Convenient online submission

- Rigorous peer review

- Open access: articles freely available online

- High visibility within the field

- Retaining the copyright to your article

Submit your next manuscript at $\boldsymbol{\nabla}$ springeropen.com 